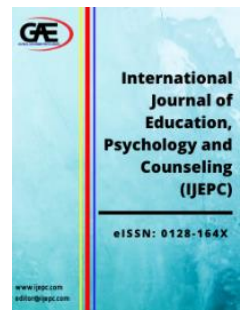

\author{
INTERNATIONAL JOURNAL OF \\ EDUCATION, PSYCHOLOGY \\ AND COUNSELLING \\ (IJEPC) \\ www.ijepc.com
}

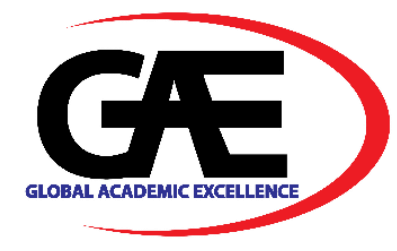

\title{
LECTURER'S PERCEPTION ON THE IMPLEMENTATION OF PROBLEM-BASED LEARNING (PBL) APPROACH IN TEACHING AND LEARNING
}

Nurazwa Ahmad ${ }^{1 *}$, Noor Aslinda Abu Seman ${ }^{2}$, Mohamad Ali Selimin ${ }^{3}$, Juliana Abdul Halip ${ }^{4}$, Wan Nurul Karimah Wan Ahmad ${ }^{5}$

$1 \quad$ Faculty of Technology Management and Business, Universiti Tun Hussein Onn Malaysia (UTHM), Malaysia Email: nurazwa@uthm.edu.my

2 Faculty of Technology Management and Business, Universiti Tun Hussein Onn Malaysia (UTHM), Malaysia Email: naslinda@uthm.edu.my

3 Faculty of Technology Management and Business, Universiti Tun Hussein Onn Malaysia (UTHM), Malaysia Email: aliselimin@uthm.edu.my

$4 \quad$ Faculty of Technology Management and Business, Universiti Tun Hussein Onn Malaysia (UTHM), Malaysia Email: julianaah@uthm.edu.my

5 Faculty of Technology Management and Business, Universiti Tun Hussein Onn Malaysia (UTHM), Malaysia Email: karimah@uthm.edu.my

Corresponding Author

\section{Article Info:}

Article history:

Received date:27.07.2021

Revised date: 10.08.2021

Accepted date: 28.09.2021

Published date: 30.09 .2021

\section{To cite this document:}

Ahmad, N., Seman, N. A. A., Selimin, M. A., Halip, J. A., \& Ahmad, W. N. K. W. (2021). Lecturer's Perception On The Implementation of ProblemBased Learning (PBL) Approach In Teaching And Learning. International Journal of Education, Psychology and Counseling, 6 (42), 492-507.

DOI: $10.35631 /$ IJEPC.642040

\begin{abstract}
:
Problem-based learning (PBL) was known as the student-centered pedagogy where it involves the student to experience solving complex real-world problems and the teacher acts as a facilitator in crafting trigger materials to promote the learning concepts. This study aims to investigate and identify the level of usefulness and challenges as well as the level of student achievement through the perception of academic staff' on the implementation of PBL in classrooms in Malaysia. A quantitative study was conducted, and the data was collected through a survey questionnaire on 98 lecturers all over Malaysia. The findings from the analysis indicate that lectures in Malaysia have a high perception of PBL implementation in the classroom. Overall, the findings enhance the understanding of higher institution lecturers' perception of PBL in terms of the usefulness of PBL as one dynamic and active approach that transforms dramatically the routine lecture-based learning. Findings also suggest that sufficient training to learners is required in implementing PBL effectively, thus indirectly facilitate the focus of students that lead to the achievement of course learning outcomes.
\end{abstract}




\section{Introduction}

Problem-based learning (PBL) is a student-centered based of teaching and learning approach. PBL application and implementation is not new to the academic environment especially in Malaysian Higher Education Institutions (HEI) (Hashim \& Samsudin, 2020). It was introduced with the medical programmes more than four decades ago as an instructional method in the medical education due to restrictions in traditional teaching approaches. (Alrahlah, 2016; Dolmans et al. 2015). There are more than 15 modules of active teaching and learning methods outlined for the HE academics established by the Akademi Kepimpinan Pengajian Tinggi (AKEPT). Among those 15 modules of active learning, PBL approach is considered one of the popular curriculum innovations in education nowadays (Hashim \& Samsudin, 2020). PBL uses complex real-world problems to encourage self-directed learning of students about the topic's concepts and principles in a small group setting (Savery, 2006; Dolmans et al. 2016). During PBL, the teachers or lecturers often act as the facilitator that will monitor and guide the progress of PBL. As PBL has now becoming an emerging teaching and learning approach in Malaysia (Ramlan et al., 2020), it is applied in almost all courses such as engineering, mathematics, science, social science, literature and a few more courses.

\section{Problem Statement}

The studies on PBL had mostly covered in medical and computing domain between 2004 to 2012 (Tsai \& Chiang, 2013). It showed the trends in PBL have majored in medical education where the teachers integrating the learning with authentic or real medical problems into the learning while in computing education, practical computing skills were instilled in students by implementing PBL method during teaching and delivery in class. The rest of domains were education, social science, engineering, science, and system design. A great amount of research in PBL had covered undergraduates' students from 2004 to 2012, yet the researchers had continuously embracing the study on PBL in current years. Implementation of PBL in education was reported to exhibit superior proficient skills of the students despite using traditional teaching methods (Alrahlah, 2016). It is believed deep learning and higher order thinking problem solving skills are crucial for undergraduate students thus driving the imposition of PBL method into the higher education curricular (Ersoy, 2014). When more studies concerned on students' side i.e., (Ersoy, 2014; Breton, 1999; Raflee \& Halim, 2021; Hashim \& Samsudin, 2020; Zulkifli, 2016), less studies have focused on the teachers' perspective in bigger scope i.e., Ramlan et al. (2020) had covered lecturers' views on PBL implementation in a single higher institution. The study found a moderate level of awareness among academic staffs. Considering a need for the academics to equip undergraduate students with higher order thinking skills with long lasting knowledge in facing the Industry 4.0 future jobs, PBL implementation in teaching delivery is deemed crucial. Thus, this study is purposely conducted to contribute to the current body of knowledge on the lecturers' perceptions of PBL implementation in higher education. The following objectives are addressed in the present study: (i) to identify the level of usefulness and challenges of PBL implementation from lecturer's point of view, and (ii) to identify the level of student's academic achievement, student's social interaction, and student's personal skill from lecturer's point of view. 


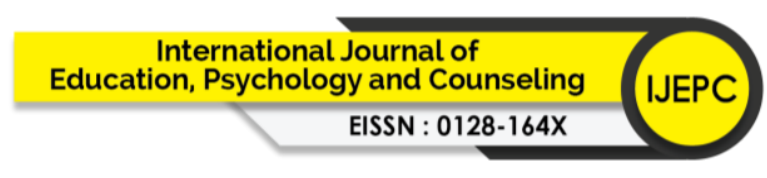

Volume 6 Issue 42 (September 2021) PP. 492-507

DOI 10.35631/IJEPC.642040

\section{Literature Review}

PBL is a well-known approach in teaching and learning delivery methods that can develop different skills of students. The main purpose of PBL is to equip students with authentic experiences that adopt active learning by incorporating learning and real-life to achieve the specific learning outcomes domain. Despite having numerous workloads in Malaysian higher education institutions, PBL requires the lecturer to allocate extra time to prepare, conduct, and assess students' achievement (Li et al., 2020; Masek \& Yamin, 2010). PBL involved many processes, and all these processes should be well documented and meet the standard set by the accreditation bodies. The lecturer should be able to give sound and clear instruction to students as well as plays an active role before, during, and after PBL. On top of that, Ramlan et al. (2020) reported that there was moderate awareness of PBL among academic staff in UTHM due to poor formal training provided on PBL as well as knowledge on how to integrate the PBL and lecture in order to achieve course learning outcomes. In other study, students agreed that the PBL is approachable to develop their soft skills or generic skills, promote self-regulated and self-directed learning (SDL), and enhance students' enthusiasm and motivation (Mpalanyi et al., 2020).

Despite the advantages of PBL, Dring (2019) stated that PBL alone is not a versatile approach without proper and sufficient supporting materials. Although examination results reveal that the introduction of PBL has improved student academic performance; there were a number of weaknesses observed in the implementation of the PBL sessions such as students not allowed to share the learning objectives to other groups to ensure each group obtains it by themselves due to unsustainable material (Hussain et al., 2019). As for the engineering course, authenticity, sustained inquiry, and public product from design space while aligning to standards and engage and coach are the elements that need to be emphasized through the exploration course (Kaushik, 2020). There are various available articles published on PBL implementation. Yet, there is limited work reported on the implementation of PBL from the perception of lecturers' worldwide especially on the students' development and achievement. Most of the articles discussed the output from students' perception (Kaushik, 2020; Parrado-Martinez, \& SanchezAndujar, 2020; Jabarullah \& Hussain, 2019; Al-Drees et al., 2015; Emerald et al., 2013).

\section{Methodology}

This study employed a quantitative method in achieving the research objectives. A set of survey questionnaires was prepared which was self-developed and adapted from Mei et al. (2019). Some of the instruments were modified to suit the context of the study. The instrument was divided into three parts. The first part, Part A focuses on the demographic profiles of the respondents and their perception on PBL method in general. There were 13 items in the demographic section. The second part, Part B focuses on the lecturer's perception on the usefulness of PBL approach and challenges in implementing PBL in class with consist 15 items in total. While the third part, Part C focuses on the lecturer's perception on students' performance with overall 14 items altogether. The Cronbach's coefficient alpha for usefulness of PBL approach is 0.928 , challenges of PBL implementation is 0.871, student's academic achievement is 0.903 , student's social interaction is 0.937 , and student's personal skills is 0.904. As according to Cronbach and Gleser (1959), all of the constructs' Cronbach's $\alpha$ which ranging from 0.871 to 0.937 were suggested as psycho-metrically sound due to high reliability coefficient value and can be used for further research activity. The reliability coefficient of the constructs is depicted in Table 1. All items under Part B and Part C were measured using 5points Likert scale. This study was conducted to lecturers of higher education institutions in 


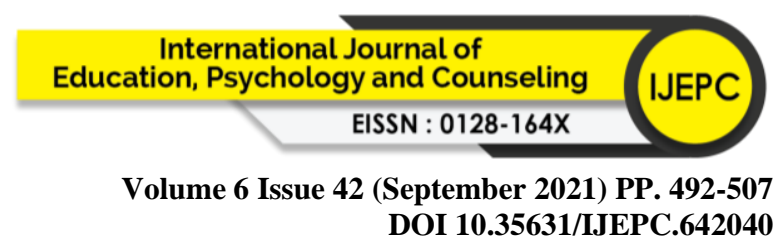

Malaysia. It was administrated to all academic staffs and none to the students or non-academic staffs. Due to enormous number of populations inclusive public and private universities, higher education institutions and colleges, snowballing sampling technique was employed to reach the large sample. Snowballing works as one sample identified will lead to another sample. The data collection was conducted during Covid-19 pandemic breakout, thus delimited our method of collecting data due to Movement Control Order (MCO) enforcement by the government. Therefore, the survey was distributed through the most convenient method through online medium of Google Form by using English as a language medium. It took about one week to complete the data collection with final 102 samples collected. However only 98 returned response were usable for further analysis. Four unusable returned responses were excluded from further analysis because they are incomplete. All 98 usable responses were analyzed using SPSS version 26.0. Based on the study's objectives, which are to identify the perceptions level on PBL among academic staffs of universities, higher education institutions and colleges in Malaysia, descriptive analyses were applied to get the frequency, percentage and mean score. The mean scores were interpreted as low for $1.00 \leq \mathrm{M} \leq 2.34$, moderate for $2.35 \leq \mathrm{M} \leq 3.67$, and high for $3.68 \leq \mathrm{M} \leq 5.00$ (Chua, 2006). The result scores and discussion are presented in the next section.

Table 1: Reliability Analysis

\begin{tabular}{lcc}
\hline \multicolumn{1}{c}{ Construct } & No. of Item & Cronbach's $\boldsymbol{\alpha}$ \\
\hline Usefulness of PBL approach & 8 & 0.928 \\
Challenges of PBL implementation & 7 & 0.871 \\
Student's academic achievement & 5 & 0.903 \\
Student's social interaction & 6 & 0.937 \\
Student's personal skills & 3 & 0.904 \\
\hline
\end{tabular}

\section{Results and Discussion}

\section{Descriptive Analysis}

The demographic variables of the lecturers who voluntarily participated in this study include gender, age, their education background, duration of teaching experiences, their current institutions, current job roles and the teaching areas. According to the information depicted in Table 2, it can be observed that majority of the respondent are female $(69.4 \%, n=68)$ while the rest $(30.6 \%, \mathrm{n}=30)$ are their male counterparts. This indicates that more than half of the respondents are female. The respondents were majority $(62.24 \%, \mathrm{n}=61)$ aged of 31 to 40 years old, followed by respondents aged 41 to 50 years old $(24.49 \%, \mathrm{n}=24)$, then respondents aged above 50 years old $(7.14 \%, n=7)$, and lastly lecturers aged 20 to 30 years old are the least response $(6.12 \%, \mathrm{n}=6)$. More than half $(68.37 \%, \mathrm{n}=67)$ of the respondents hold a doctorate degree followed by master's and bachelor's degree $(25.51 \%, \mathrm{n}=25 ; 6.12 \%, \mathrm{n}=6)$ respectively.

Table 2: Demographic Profiles of Respondents.

\begin{tabular}{lcc}
\hline \multicolumn{1}{c}{ Item } & $\begin{array}{c}\text { Frequency } \\
(\mathbf{n = 9 8})\end{array}$ & $\begin{array}{c}\text { Percentage } \\
(\mathbf{\%})\end{array}$ \\
\hline $\begin{array}{l}\text { Gender } \\
\text { Male }\end{array}$ & 30 & 30.6 \\
Female & 68 & 69.4 \\
$\begin{array}{l}\text { Age } \\
20 \text { to 30 years }\end{array}$ & 6 & 6.12 \\
ght $\odot$ GLOBAL ACADEMIC EXCELLENCE $(M)$ SDN BHD - All rights reserved & &
\end{tabular}


31 to 40 years

41 to 50 years

above 50 years

Education background

Bachelor's degree

Master's degree

$\mathrm{PhD}$

\section{Category of academic institution}

Public university

Private university

Public higher education institution

Private higher education institution

Job position

Lecturer

Senior Lecturer

Associate Professor

Teaching experience

3 years and less

4 - 6 years

7 - 9 years

10 - 12 years

More than 12 years

Teaching area

Management and business

Science, technology and engineering

Social science, literature and art

Others
Volume 6 Issue 42 (September 2021) PP. 492-507

DOI 10.35631/IJEPC.642040

\section{1}

24

62.24

7

24.49

7.14

\section{6}

6.12

25

25.51

67

68.37

\section{3}

64.29

12

12.24

9

9.18

14

14.29

50

51.02

40

40.82

8

8.16

29

29.59

22.45

8

8.16

16

16.33

23

23.47

42

42.86

40

40.82

9

7

Majority of the respondents are from the public institutions $(73.47 \%, \mathrm{n}=72)$, while the remaining $(26.53 \%, \mathrm{n}=26)$ are from the private institutions. $51.02 \%$ of the respondents are lecturers $(n=50), 40.82 \%$ are senior lecturers $(n=40)$, and $8.16 \%$ are associate professors $(n=8)$. About more than half of the respondents have less than 10 years teaching experience, whilst the remaining have 10 years and more teaching experience. This indicates that a lot of respondents are well versed with the teaching roles because they have been practicing teaching and learning more than ten years. Figure 1 displays clearly the list of institutions who voluntarily involved in the survey. The 98 respondents are from 22 different institutions which most of the respondents are from Universiti Tun Hussein Onn Malaysia (UTHM) $(n=30)$, Kolej Teknologi Darulnaim (KTD) $(n=11)$, Universiti Utara Malaysia (UUM) (n=9), Universiti Teknologi Malaysia (UTM) $(n=8)$, and equally 7 respondents from Universiti Kuala Lumpur Malaysian Institute of Industrial Technology (UniKL MITEC) and Universiti Putra Malaysia (UPM). These combinations formed about $72 \%$ of the whole respondents. The responses gathered from different institutions supplant the researchers with respondent of variety background. To add more, $83.68 \%$ of the respondent teaches in science, technology, engineering, management and business. Only $9.18 \%$ of respondents teach in social science, literature and art. The remaining $7.14 \%$ teaches in technical and vocational, law, multimedia, statistics, and tourism and hospitality. Even though their teaching area background are exclusively differed from one another, but they all implement the same learning methods for example problem-based learning in classroom teaching. This shows the PBL method is not 


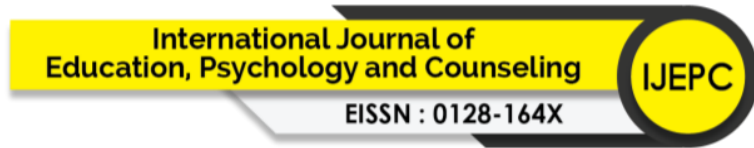

Volume 6 Issue 42 (September 2021) PP. 492-507

DOI 10.35631/IJEPC.642040

limited to any area of learning. It can suit all areas of teaching, but it needs to be properly planned and structured to ensure its successful and effective implementation.

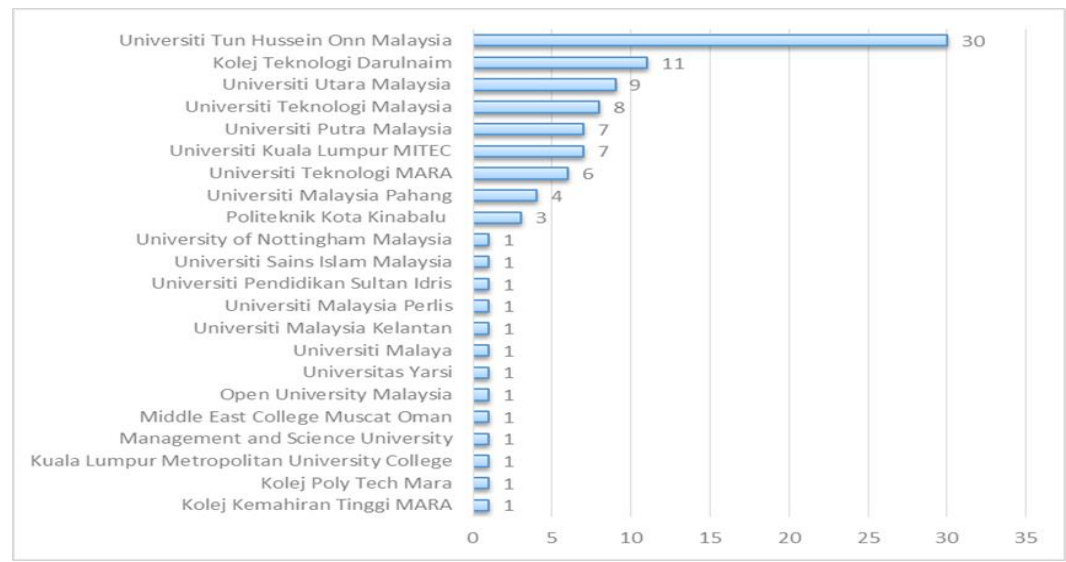

Figure 1: Academic Institutions

Respondents were asked whether they have ever heard about PBL before. The result in Figure 2 shows that almost all the respondent which is $98.98 \%$ were familiar with the PBL term throughout their teaching period. PBL was considered as a common term to almost all the lecturers.

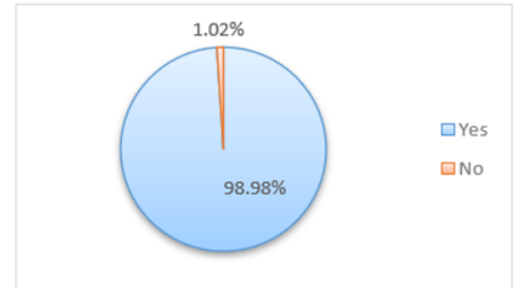

Figure 2: Have you ever heard about PBL?

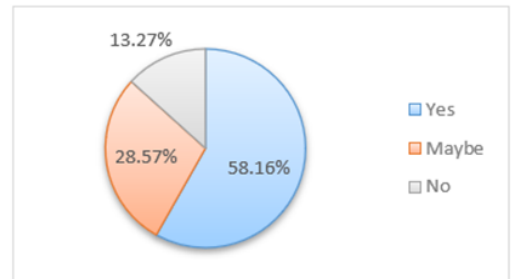

Figure 4: Do you have experience teaching using PBL in class?

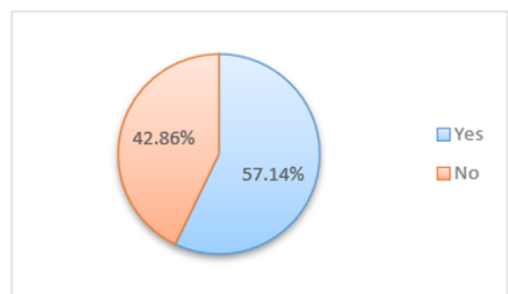

Figure 3: Have you received any training on PBL?

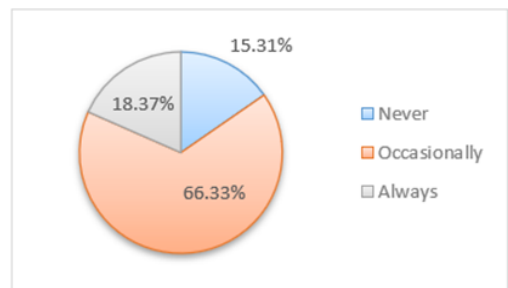

Figure 5: How often do you apply PBL in class? 


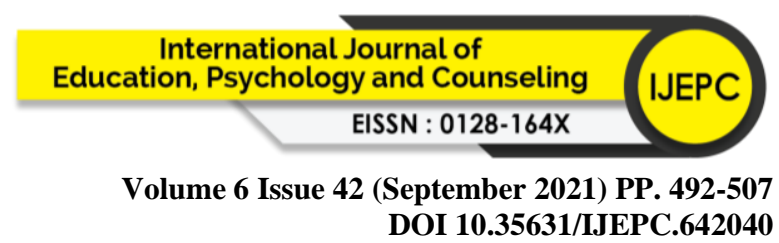

Figure 3 shows that nearly half $(42.86 \%)$ of the respondents did not received any training on PBL. It signifies that some of them had implemented PBL approach in classes with their own will, effort and method. As shown in Figure 4, 58.16\% of the respondents which equals to 57 lecturers have an experience conducting PBL approach in class while another 13 lecturers had no experience of conducting classes using PBL approach at all. The finding is quite interesting where $28.57 \%(\mathrm{n}=28)$ lecturers answered 'maybe' when they were asked whether they had any experience implementing PBL approach in class. It is revealed that this group of lecturers are partly the lecturers who did not have any PBL training at all. They were not sure but believed the method they applied in class is some sort of problem- based approach. Over 60 lecturers have applied the PBL approach in class occasionally (Figure 5). The findings presented lecturers did not apply PBL methods all the times. With years of experiences in teaching and learning, it is believed that lecturers also use other teaching methods such as case-based learning, project-based learning, self-directed learning, and several other methods in addition to problem-based learning. When they were asked (Figure 6) whether they are interested to implement PBL in class, most of them $(82.65 \%, \mathrm{n}=81)$ answered a 'yes'. This response proved that lecturers are aware about the advantages from implementing this kind of method in the classroom. PBL is not a new method in teaching, only its implementation steps that require careful preparation are among the factors that lecturers do not use this method regularly in the classroom.

\section{Lecturer's Perception on Usefulness of Problem-Based Learning Approach}

Respondents were asked about their views regarding the usefulness of problem-based learning approach. Table 3 reported the highest mean score of perception is item 3 ' $P B L$ is a refreshing change from the routine of day-to-day learning in the classroom' with the mean value of 4.20. It was followed by item 2 'PBL is able to bring more out from a learner than the traditional teacher-centered approach' with the mean value is 4.18. Majority respondents had higher level agreement on the usefulness of PBL as a refreshing change from the routine of day-today learning. This is supported by Preeti et al. (2013) who stated that there is a need of innovation and creativity in learning and assessment such as adoption of PBL as lively learning compared to the traditional passive spoon-feeding technique. Majority respondents also agreed that PBL is very useful to generate more learning output from learner rather than lecturer-based learning approach. This is because PBL is a method of teaching that emphasis on studentcentered learning that related to real life issues or problems which facilitate learners to increase lifelong learning culture (Zakaria et al., 2019; Li \& Tsai, 2017; Raiyn \& Tilchin, 2015).

Meanwhile, the lowest mean score was recorded for the item 4 ' $P B L$ works for almost all types of subjects, such as engineering, business, design, IT and applied sciences' with the mean value of 3.90. The least agreement on item 4 probably due to lack of knowledge on PBL concept. On top of that, respondents assumed that PBL are less suitable to be used in certain teaching area. However, some studies have confirmed the suitability of PBL in several subjects such as science and engineering to business and language studies in encouraging students' skills effectively (Hirshfield and Koretsky, 2017; Jusoh et al. 2017). 
Volume 6 Issue 42 (September 2021) PP. 492-507

DOI 10.35631/IJEPC.642040

Table 3: Usefulness of Problem-Based Learning Approach.

\begin{tabular}{|c|c|c|c|c|c|c|c|c|c|}
\hline No. & Item & SD & D & $\mathbf{N}$ & $\mathbf{A}$ & SA & Mean & SD & Result \\
\hline 1. & $\begin{array}{l}\text { PBL is a } \\
\text { suitable } \\
\text { approach for } \\
\text { learning }\end{array}$ & $\begin{array}{c}2 \\
(2.0 \%)\end{array}$ & $\begin{array}{c}1 \\
(1.0 \%)\end{array}$ & $\begin{array}{c}14 \\
(14.3 \%)\end{array}$ & $\begin{array}{c}53 \\
(54.1 \%)\end{array}$ & $\begin{array}{c}28 \\
(28.6 \%)\end{array}$ & 4.06 & 0.81 & High \\
\hline 2. & $\begin{array}{l}\text { PBL is able } \\
\text { to bring } \\
\text { more out } \\
\text { from a } \\
\text { learner than } \\
\text { the } \\
\text { traditional } \\
\text { teacher- } \\
\text { centered } \\
\text { approach }\end{array}$ & $\begin{array}{c}2 \\
(2.0 \%)\end{array}$ & $\begin{array}{c}1 \\
(1.0 \%)\end{array}$ & $\begin{array}{c}7 \\
(7.1 \%)\end{array}$ & $\begin{array}{c}55 \\
(56.1 \%)\end{array}$ & $\begin{array}{c}33 \\
(33.7 \%)\end{array}$ & 4.18 & 0.78 & High \\
\hline 3. & $\begin{array}{l}\text { PBL is a } \\
\text { refreshing } \\
\text { change from } \\
\text { the routine } \\
\text { of day-to- } \\
\text { day learning } \\
\text { in the } \\
\text { classroom }\end{array}$ & $\begin{array}{c}2 \\
(2.0 \%)\end{array}$ & $\begin{array}{c}1 \\
(1.0 \%)\end{array}$ & $\begin{array}{c}8 \\
(8.2 \%)\end{array}$ & $\begin{array}{c}51 \\
(52.0 \%)\end{array}$ & $\begin{array}{c}36 \\
(36.7 \%)\end{array}$ & 4.20 & 0.80 & High \\
\hline 4. & $\begin{array}{l}\text { PBL works } \\
\text { for almost all } \\
\text { types of } \\
\text { subjects, } \\
\text { such as } \\
\text { engineering, } \\
\text { business, } \\
\text { design, IT } \\
\text { and applied } \\
\text { sciences }\end{array}$ & $\begin{array}{c}2 \\
(2.0 \%)\end{array}$ & $\begin{array}{c}5 \\
(5.1 \%)\end{array}$ & $\begin{array}{c}18 \\
(18.4 \%)\end{array}$ & $\begin{array}{c}49 \\
(50.0 \%)\end{array}$ & $\begin{array}{c}24 \\
(24.5 \%)\end{array}$ & 3.90 & 0.90 & High \\
\hline 5. & $\begin{array}{l}\text { PBL is able } \\
\text { to measure } \\
\text { the depth of } \\
\text { learning } \\
\text { appropriately }\end{array}$ & $\begin{array}{c}1 \\
(1.0 \%)\end{array}$ & $\begin{array}{c}3 \\
(3.1 \%)\end{array}$ & $\begin{array}{c}20 \\
(20.4 \%)\end{array}$ & $\begin{array}{c}44 \\
(44.9 \%)\end{array}$ & $\begin{array}{c}30 \\
(30.6 \%)\end{array}$ & 4.01 & 0.86 & High \\
\hline 6. & $\begin{array}{l}\text { PBL helps a } \\
\text { learner to } \\
\text { solve daily } \\
\text { problems } \\
\text { effectively } \\
\text { too }\end{array}$ & $\begin{array}{c}2 \\
(2.0 \%)\end{array}$ & $\begin{array}{c}3 \\
(3.1 \%)\end{array}$ & $\begin{array}{c}8 \\
(8.2 \%)\end{array}$ & $\begin{array}{c}57 \\
(58.2 \%)\end{array}$ & $\begin{array}{c}28 \\
(28.6 \%)\end{array}$ & 4.08 & 0.82 & High \\
\hline 7. & $\begin{array}{l}\text { It is more } \\
\text { effective to } \\
\text { learn as a }\end{array}$ & $\begin{array}{c}2 \\
(2.0 \%)\end{array}$ & $\begin{array}{c}3 \\
(3.1 \%)\end{array}$ & $\begin{array}{c}17 \\
(17.3 \%)\end{array}$ & $\begin{array}{c}41 \\
(41.8 \%)\end{array}$ & $\begin{array}{c}35 \\
(35.7 \%)\end{array}$ & 4.06 & 0.92 & High \\
\hline
\end{tabular}




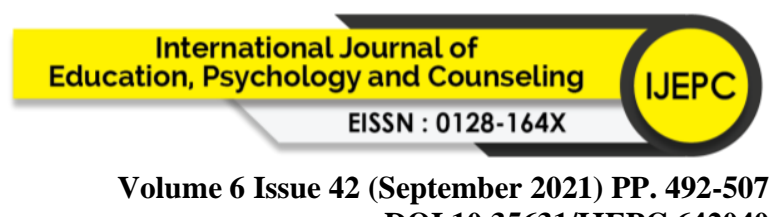

Volume 6 Issue 42 (September 2021) PP. 492-507

DOI 10.35631/IJEPC.642040

group than to

learn

individually

8. PBL is a

necessary

approach in

meeting the

changing

needs of the

learning

environment

$\begin{array}{cccccccc}3 & - & 13 & 56 & 26 & 4.04 & 0.82 & \text { High } \\ (3.1 \%) & & (13.3 \%) & (57.1 \%) & (26.5 \%) & & & \end{array}$

$\begin{array}{llll}\text { Average Usefulness of PBL } & 4.07 & 0.68 & \text { High }\end{array}$

\section{Lecturer's Perception on Challenges in Problem-Based Learning Implementation}

Pertaining to the lecturer's perception on challenges in problem-based learning implementation, the respondents mostly agreed that the learners should be properly trained to handle PBL with the mean value is 4.21. As stressed by Al-Drees et al. (2015), the insufficient and incorrect training on students by tutors may drive to poor performance of PBL execution. Additionally, Zwaal and Otting (2015) also mentioned that the successful of PBL implementation required the suitable training in management for both students and tutors. Thus, it indicates that the initial proper training becomes the key challenge that need more attention in order to achieve learning goals and ensure PBL implementation successfully.

Most of respondents have least agreement on item 1 'Age group is not a barrier in $P B L$ ' with the mean score is 3.73. This indicates that age different between senior and junior students during PBL process did not become the main challenge to lecturer in implementing PBL. The finding from the study of Noura (2014) revealed that senior students who aged more than 20 years that had former experience in learning performed more independently in PBL class compared to junior students who aged 16-20 years old. Robinson (2014) also found that junior students were manipulated by senior students and contributed to resilient learning environment during PBL practice. However, Robinson (2014) also added that the different of age group become barrier to PBL implementation in developing critical thinking with group members.

Table 4: Challenges in Problem-Based Learning Implementation

\begin{tabular}{|c|c|c|c|c|c|c|c|c|c|}
\hline No & Item & SD & D & $\mathbf{N}$ & A & SA & $\begin{array}{c}\text { Mea } \\
\mathbf{n}\end{array}$ & SD & Result \\
\hline 1. & $\begin{array}{l}\text { Age group is not a } \\
\text { barrier in } \mathrm{PBL}\end{array}$ & $\begin{array}{c}3 \\
(3.1 \%)\end{array}$ & $\begin{array}{c}11 \\
(11.2 \%)\end{array}$ & $\begin{array}{c}22 \\
(22.4 \%)\end{array}$ & $\begin{array}{c}35 \\
(35.7 \%)\end{array}$ & $\begin{array}{c}27 \\
(27.6 \%)\end{array}$ & 3.73 & 1.08 & High \\
\hline 2. & $\begin{array}{l}\text { Personal } \\
\text { reflection is an } \\
\text { important element } \\
\text { in PBL to help } \\
\text { discover new } \\
\text { things about the } \\
\text { leaner }\end{array}$ & $\begin{array}{c}1 \\
(1.0 \%)\end{array}$ & $\begin{array}{c}3 \\
(3.1 \%)\end{array}$ & $\begin{array}{c}12 \\
(12.2 \%)\end{array}$ & $\begin{array}{c}48 \\
(49.0 \%)\end{array}$ & $\begin{array}{c}34 \\
(34.7 \%)\end{array}$ & 4.13 & 0.82 & High \\
\hline 3. & $\begin{array}{l}\text { Learners should } \\
\text { be properly }\end{array}$ & $\begin{array}{c}1 \\
(1.0 \%)\end{array}$ & $\begin{array}{c}2 \\
(2.0 \%)\end{array}$ & $\begin{array}{c}11 \\
(11.2 \%)\end{array}$ & $\begin{array}{c}45 \\
(45.9 \%)\end{array}$ & $\begin{array}{c}39 \\
(39.8 \%)\end{array}$ & 4.21 & 0.80 & High \\
\hline
\end{tabular}


trained to handle

PBL
4. $\quad$ PBL requires strong facilitation
skills of the teachers

$\begin{array}{cc}1 & 2 \\ (1.0 \%) & (2.0 \%)\end{array}$

10
$10.2 \%$

50
$(51.0 \%)$

35

4.18

0.78

High
5. The best way of learning is through learning from problem

6. The power of questioning is the success factor in

2
$(2.0 \%)$

4
$(4.1 \%)$

13

2

2
$(2.0 \%)$
16
$(16.3 \%)(49.0 \%)(30.6 \%)$

$(2.0 \%)$

$\begin{array}{ccc}46 & 33 & 4.0 \\ (46.9 \%) & (33.7 \%)\end{array}$

4.06

0.91 High

$(13.3 \%)(46.9 \%)(33.7 \%)$

PBL

7. The lack of systematic structure in PBL

$\begin{array}{cc}2 & 2 \\ (2.0 \%) & (2.0 \%)\end{array}$

$\begin{array}{ccc}15 & 51 & 28 \\ (15.3 \%) & (52.0 \%) & (28.6 \%)\end{array}$

4.03

0.84

High

Average Challenges in PBL $4.06 \quad 0.65$ High

\section{Lecturer's Perception on Student's Academic Achievement}

Table 5 shows the lecturer's perception on student's academic achievement. From the table, it can be seen that there are two similar highest mean score which is 3.85. Those items are item 1 'I feel that using PBL will achieve course learning outcome' and item 5 'Through PBL activities, learning makes my students more focus on the subject matter'. This study found that majority respondents agreed that PBL can help students to reach course learning outcome. According to Klegeris and Hurren (2011), PBL is an innovative learning approach that involves collaborative process as a whole in achieving students learning goal and their engagement in learning. Besides, respondents also believed that PBL class can increase the students' concentration on related topic. PBL method is a useful teaching technique in improving students understanding of related concepts or given topic and finally turned students to adopt self-directed learning (Gorghiu et al., 2015; Gunter \& Alpat, 2017).

However, respondents also feel slightly agreed on item 3 'My students understand the problem material in the PBL more than they study the material using other method' with the mean value is 3.57. This indicates that respondents felt PBL is not only the practice or method that can help student to develop their critical thinking in understanding problem material. Although Prosser (2004) revealed that PBL students performed well or slightly better than students of lecturebased learning, Didem (2016) emphasized that the learners also deal with several difficulties like identifying real problems and finding the solutions during the practice of PBL. Students also found to have difficulty in improving critical thinking skills during PBL class (Zetriuslita, Wahyudin, \& Jarnawi, 2017). 
Table 5: Descriptive Statistics of Student's Academic Achievement.

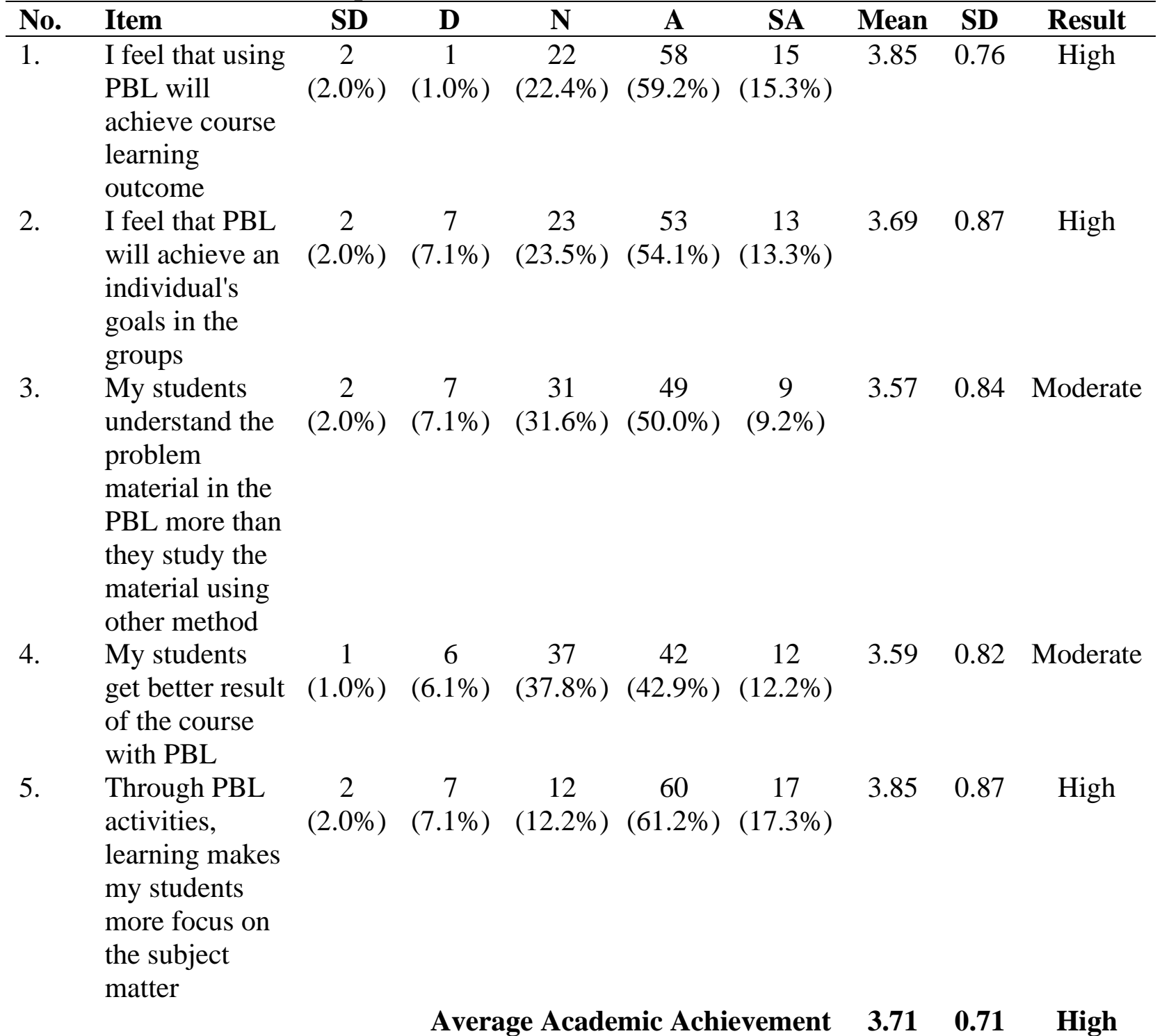

\section{Lecturer's Perception on Student's Social Interaction}

Respondents were asked about their view regarding the perception of lecturer on student's social interaction based on the implementation of PBL. As illustrated in Table 6, item 4 ' $P B L$ gives my students an idea of how to solve the problem through group discussion', reported the highest mean value which is 4.13. This result is similar by finding of Al-Drees et al. (2015) who discovered that students gained deep learning through small group discussion and practice of self-directed learning in PBL. This is also supported by Klegeris and Hurren (2011) who stated that the discussion among group member triggered them find the required information and examine the problems further.

A lowest mean score is 3.77 which recorded by item 5 'My students got equal chances to learn in PBL method'. With regard to the equal opportunity given to students during PBL approach, lecturer should prepare the best possible chance to every student in terms of providing all 
Volume 6 Issue 42 (September 2021) PP. 492-507

DOI 10.35631/IJEPC.642040

available methods and learning theories and use whichever is best suited to each student, group, or class (Pagander \& Read, 2014).

Table 6: Descriptive Statistics of Student's Social Interaction.

\begin{tabular}{|c|c|c|c|c|c|c|c|c|c|}
\hline No. & Item & SD & D & $\mathbf{N}$ & A & SA & Mean & SD & Result \\
\hline 1. & $\begin{array}{l}\text { PBL gives my } \\
\text { students more } \\
\text { confidence during } \\
\text { group discussion }\end{array}$ & $\begin{array}{c}2 \\
(2.0 \%)\end{array}$ & $\begin{array}{c}2 \\
(2.0 \%)\end{array}$ & $\begin{array}{c}26 \\
(26.5 \%)\end{array}$ & $\begin{array}{c}46 \\
(46.9 \%)\end{array}$ & $\begin{array}{c}22 \\
(22.4 \%)\end{array}$ & 3.86 & 0.86 & High \\
\hline 2. & $\begin{array}{l}\text { PBL teaches my } \\
\text { students how to } \\
\text { take care of each } \\
\text { other in the group }\end{array}$ & $\begin{array}{c}2 \\
(2.0 \%)\end{array}$ & $\begin{array}{c}6 \\
(6.1 \%)\end{array}$ & $\begin{array}{c}19 \\
(19.4 \%)\end{array}$ & $\begin{array}{c}54 \\
(55.1 \%)\end{array}$ & $\begin{array}{c}17 \\
(17.3 \%)\end{array}$ & 3.80 & 0.87 & High \\
\hline 3. & $\begin{array}{l}\text { My students like } \\
\text { to share their } \\
\text { knowledge with } \\
\text { their group } \\
\text { member and get } \\
\text { more from } \\
\text { another during } \\
\text { PBL }\end{array}$ & $\begin{array}{c}2 \\
(2.0 \%)\end{array}$ & $\begin{array}{c}4 \\
(4.1 \%)\end{array}$ & $\begin{array}{c}24 \\
(24.5 \%)\end{array}$ & $\begin{array}{c}43 \\
(43.9 \%)\end{array}$ & $\begin{array}{c}25 \\
(25.5 \%)\end{array}$ & 3.87 & 0.92 & High \\
\hline 4. & $\begin{array}{l}\text { PBL gives my } \\
\text { students an idea } \\
\text { of how to solve } \\
\text { the problem } \\
\text { through group } \\
\text { discussion }\end{array}$ & $\begin{array}{c}2 \\
(2.0 \%)\end{array}$ & - & $\begin{array}{c}14 \\
(14.3 \%)\end{array}$ & $\begin{array}{c}49 \\
(50.0 \%)\end{array}$ & $\begin{array}{c}33 \\
(33.7 \%)\end{array}$ & 4.13 & 0.81 & High \\
\hline 5. & $\begin{array}{l}\text { My students got } \\
\text { equal chances to } \\
\text { learn in PBL } \\
\text { method. }\end{array}$ & $\begin{array}{c}2 \\
(2.0 \%)\end{array}$ & $\begin{array}{c}6 \\
(6.1 \%)\end{array}$ & $\begin{array}{c}22 \\
(22.4 \%)\end{array}$ & $\begin{array}{c}51 \\
(52.0 \%)\end{array}$ & $\begin{array}{c}17 \\
(17.3 \%)\end{array}$ & 3.77 & 0.88 & High \\
\hline 6. & $\begin{array}{l}\text { My students can } \\
\text { learn how to } \\
\text { cooperate and } \\
\text { collaborate } \\
\text { through PBL }\end{array}$ & $\begin{array}{c}2 \\
(2.0 \%)\end{array}$ & - & $\begin{array}{c}16 \\
(16.3 \%)\end{array}$ & $\begin{array}{c}48 \\
(49.0 \%)\end{array}$ & $\begin{array}{c}32 \\
(32.7 \%)\end{array}$ & 4.10 & 0.82 & High \\
\hline & & & & \multicolumn{3}{|c|}{ Average Social Interaction } & 3.92 & 0.75 & High \\
\hline
\end{tabular}

\section{Lecturer's Perception on Student's Personal Skill}

Table 7 revealed the lecturer's perception on student's personal skill and discovered that the highest mean score is item 2 'Through PBL, my students can understand the problem matters better by discussing with group members' with the mean value is 4.12 . This is line with the study by Klegeris and Hurren (2011) and Al-Drees et al. (2015) as mentioned above. This indicated that the group discussion plays important role to ensure the learning goal can be achieved. Sockalingam et al. (2012) explained the role of a group in PBL method in encouraging students' interest and involvement among members to find and solve the problems whereby will push them to develop teamwork, brainstorming and discussions. 


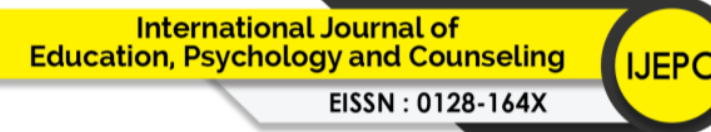

Volume 6 Issue 42 (September 2021) PP. 492-507

DOI 10.35631/IJEPC.642040

Meanwhile, several respondents had slight agreement on item 3 'My students improved a lot in writing skill through PBL method' with the mean value is 3.70. According to Brown et al. (2016), PBL approach can help students to improve their writing skills and actively participate in learning during PBL. PBL can be one of innovative strategies in teaching writing discussion text in which help students to develop their writing skill (Milah, 2015).

Table 7: Descriptive Statistics of Student's Personal Skill.

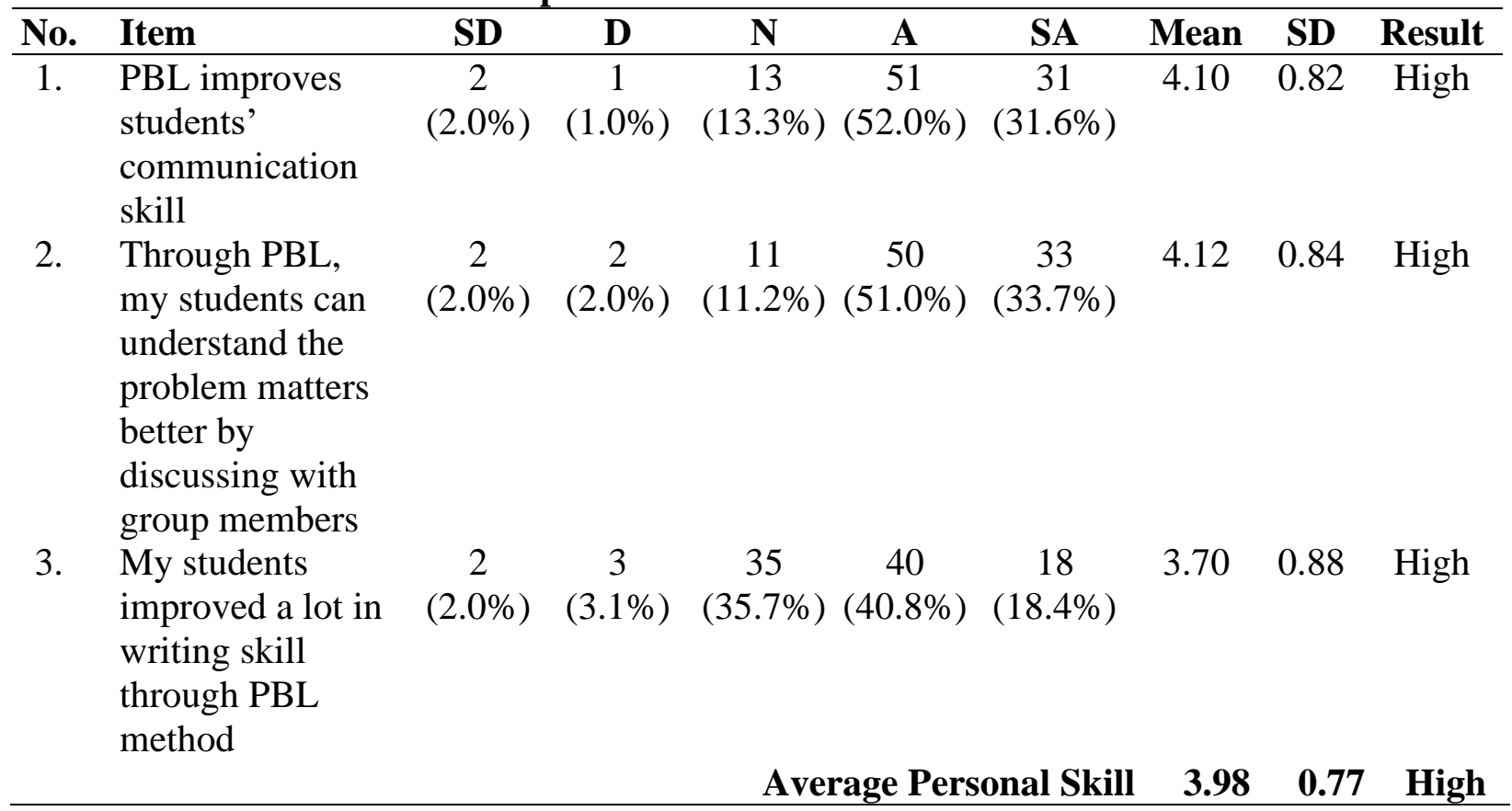

\section{Conclusion}

This study examines the perception of lecturers on the usefulness and challenges of PBL implementation. This study also investigates the perception of lecturers of PBL on student's academic achievement, student's social interaction and student's personal skills. Among ninety-eight lecturers participated in the survey, 98.98\% have heard about PBL, but only 57.14\% have received training on PBL and $84.70 \%$ implemented the approach in the courses that involved in PBL. Therefore, it could be assumed that the level of perception of PBL among higher institution lecturers in Malaysia is rather high. This is reflected in their perception of the usefulness, the challenges, perception on student's academic achievement, perception on student's social interaction and perception on student's personal skills that associated with PBL. Overall, the findings enhance the understanding of higher institution lecturers' perception of PBL in terms of the usefulness of PBL as one of dynamic and active approach that transformed dramatically the routine lecture-based learning. Findings also revealed that sufficient training to learners is required in implementing PBL effectively, thus indirectly facilitate the focus of students that lead to the achievement of course learning outcomes. Active group discussion among students also improves critical thinking skills significantly thus improve social interaction and personal skills of students. Future studies on factors such as infrastructure availability and class size that could restrict PBL, the use of digital and information technologies that could help facilitate its implementation can enhance the 


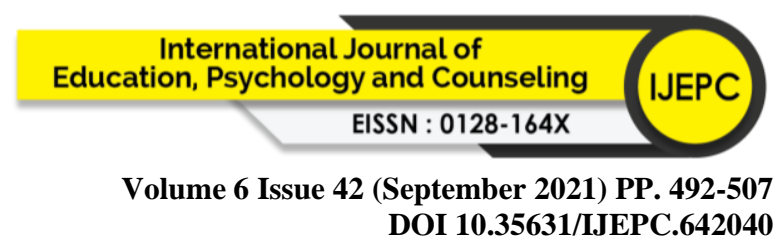

knowledge on PBL implementation itself. Higher institution and lecturers should therefore explore and use various approaches to address the challenges associated with PBL effectively.

\section{Acknowledgement}

The authors would like to extend their gratitude to Universiti Tun Hussein Onn Malaysia for financial support. All those who contributed direct and indirectly are thanked.

\section{Reference}

Al-Drees, A. A., Khalil, M. S., Irshad, M., \& Abdulghani, H. M. (2015). Students' perception towards the problem-based learning tutorial session in a system-based hybrid curriculum, Saudi Medical Journal, 36(3), 341-348.

Alrahlah, A. (2016). How effective the problem-based learning (PBL) in dental education. A critical review. The Saudi dental journal, 28(4), 155-161.

Breton, G. (1999). Some empirical evidence on the superiority of the problem-based learning (PBL) method. Accounting Education, 8(1), 1-12.

Brown, S. W., Lawless, K. A., Rhoads, C., Newton, S. D., \& Lynn, L. (2016). Increasing Students' Science Writing Skills through a PBL Simulation. In Proceedings of the 13th International Conference on Cognition and Exploratory Learning in the Digital Age. Mannheim: International Association for Development of the Information Society. 8694

Chua, Y. P. (2006). Basic Research Statistics (Book 2). Kuala Lumpur: McGraw-Hill.

Cronbach, L. J., \& Gleser, G. C. (1959). Interpretation of reliability and validity coefficients: Remarks on a paper by Lord. Journal of Educational Psychology, 50(5), 230-237.

Didem, İ. E. (2016). Examination of Pre-Service Science Teachers Activities Using Problem Based Learning Method. Educational Research and Reviews, 11, 37-47. https://doi.org/10.5897/ERR2015.2424

Dolmans, D., Michaelsen, L., Van Merrienboer, J., \& van der Vleuten, C. (2015). Should we choose between problem-based learning and team-based learning? No, combine the best of both worlds!. Medical Teacher, 37(4), 354-359.

Dring, J.C. (2019). Problem-based learning - experiencing and understanding the prominence during medical school: perspective. Annals of Medicine and Surgery, 47, $27-28$.

Emerald, N. M., Aung, P. P., Han, T. Z., Yee, K. T., Myint, M. H., Soe, T. T., \& Oo, S. S. (2013). Students' perception of problem-based learning conducted in phase 1 medical program, UCSI University, Malaysia. South East Asian Journal of Medical Education, 7(2), 45-48.

Ersoy, E. (2014). The effects of problem-based learning method in higher education on creative thinking. Procedia-Social and Behavioral Sciences, 116, 3494-3498.

Gorghiu, G., Drăghicescu, L. M., Cristea, S., Petrescu, A.-M., \& Gorghiu, L. M. (2015). Problem-Based Learning-An Efficient Learning Strategy in the Science Lessons Context. Procedia-Social and Behavioral Sciences, 191, 1865-1870. https://doi.org/10.1016/j.sbspro.2015.04.570

Gunter, T., \& Alpat, S. K. (2017). The Effects of Problem-Based Learning (PBL) on the Academic Achievement of Students Studying "Electrochemistry". Chemistry Education Research and Practice, 18, 78-98. https://doi.org/10.1039/C6RP00176A

Hashim, I. \& Samsudin, S. (2020). Practices of problem-based learning (PBL) in teaching Islamic studies in Malaysian public universities, International Journal of Innovation, Creativity and Change, 11(10), 117-129. 


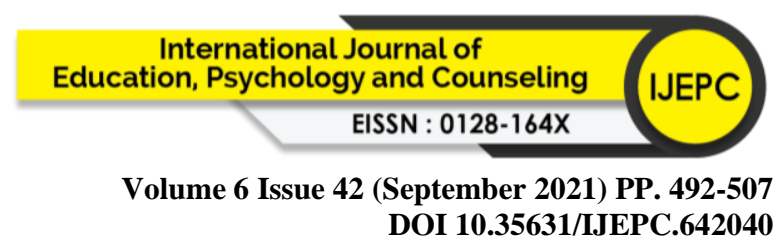

Hirshfield, L., \& Koretsky, M. D. (2017). Gender and participation in an engineering problembased learning environment. Interdisciplinary Journal of Problem-Based Learning, 12(1), 2.

Hussain, M., Sahudin, S., Samah, N. H. A., \& Anuar, N. K. (2019). Students perception of an industry based approach problem based learning (PBL) and their performance in drug delivery courses. Saudi Pharmaceutical Journal, 27, 274-282.

Jabarullah, N. H. \& Hussain, H. I. (2019). The effectiveness of problem-based learning in technical and vocational education in Malaysia. Education Training, 61(5), 552-567.

Jusoh, Z., Husni, H., Ismail, S. I., Omar, S., \& Abdullah, R. (2017, November). Implementation of embedded system design in student's final year project using problem based learning approach. IEEE 9th International Conference on In Engineering Education (ICEED). 201-205

Kaushik, M. (2020). Evaluating a First-Year Engineering Course for Project Based Learning (PBL) Essentials. Procedia Computer Science, 172, 364-369.

Klegeris, A. \& Hurren, H. (2011). Impact of problem-based learning in a large classroom setting: student perception and problem-solving skills. Advances in Physiology Education, 35, 408-415.

Li, X., Xie, F., Li, X., Li, G., Chen, X., Lv, C., \& Peng, C. (2020). Development, application, and evaluation of a problem-based learning method in clinical laboratory education. Clinica Chimica Acta, 510, 681-684.

Li, H. C., \& Tsai, T. L. (2017). The Implementation of Problem-Based Learning in a Taiwanese Primary Mathematics Classroom: Lessons Learned from the Students' Side of the Story. Educational Studies, $\quad 43, \quad 354-369$. https://doi.org/10.1080/03055698.2016.1277138

Masek, A. \& Yamin, S. (2010). Problem based learning model: a collection from the literature. Asian Social Science, 6(8), 148-156.

Mei, S. Y., Zakari, Z. B. M., Ju, S. Y., \& Ibrahim, M. (2019). The Perception of Lecturers in Malaysia toward Implementation of Cooperative Learning Method to Teach Arabic. International Journal of Recent Technology and Engineering, 8(3), 42-46. doi:10.35940/ijrte.C1028.1183S319

Milah, M. (2015). The Implementation of Problem Based Learning to Improve Writing Skill in Discussion Text: A Classroom Action Research at the Third Grade of MA NU 04 Al- Ma'arif Boja Kendal. Undergraduate Thesis, University of Walisongo, Indonesia.

Mpalanyi, M., Nalweyiso, I. D., \& Mubuuke, A. G. (2020). Perceptions of radiography students toward problem-based learning almost two decades after its introduction at Makerere University, Uganda. Journal of Medical Imaging and Radiation Sciences, 1-6.

Noura, A. (2014). Factors That Influence Performance in a Problem-based Learning Tutorial. Doctoral Thesis, Bond University.

Pagander, L., \& Read, J. (2014). Is Problem-Based Learning (PBL) An Effective Teaching Method? A Study Based on Existing Research. Linköpings universitet Lärarprogrammet.

Parrado-Martinez, P. \& Sanchez-Andujar, S. (2020). Development of competences in postgraduate studies of finance: A project-based learning (PBL) case study. International Review of Economics Education, 35, 1-12.

Preeti, B., Ashish, A. \& Shriram, G. (2013). Problem Based Learning (PBL) - An Effective Approach to Improve Learning Outcomes in Medical Teaching. Journal of Clinical and Diagnostic Research, 7(12), 2896-2897. DOI: 10.7860/JCDR/2013/7339.3787 


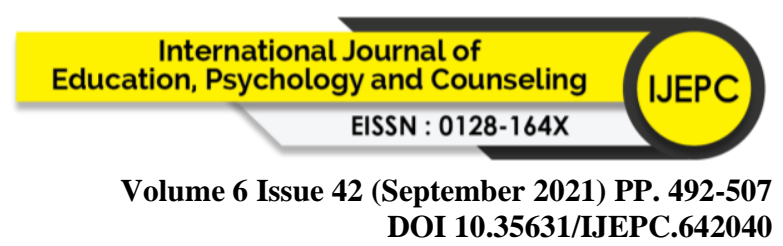

Prosser M. A. (2004) A student learning perspective on teaching and learning, with implications for problem-based learning. European Journal of Dental Education, 8, 5158

Raflee, S. S. M., \& Halim, L. (2021). The Effectiveness of Critical Thinking in Improving Skills in KBAT Problem Solving. Jurnal Pendidikan Sains Dan Matematik Malaysia, 11(1), 60-76.

Raiyn, J., \& Tilchin, O. (2015). Assessment of Adaptive PBL's Impact on HOT Development of Computer Science Students. Journal of Education and Practice, 6, 51-58.

Ramlan, N., Kadir, Z. A., Aziz, H. S., Ismail, I. N., Zan, N. S., Yusob, K. F., \& Jelani, A. N. (2020). Problem-based learning (PBL) awareness among academic staff in Universiti Tun Hussein Onn Malaysia (UTHM). Parole: Journal of Linguistics and Education, $10(1), 9-13$.

Robinson, L. (2014). Age difference and face-saving in an intergenerational problem-based learning group. Journal of Further and Higher Education, 40(4), 466-485.

Savery, J. R. (2006). Overview of problem-based learning: Definitions and distinctions. Interdisciplinary Journal of Problem-based Learning, 1(1), 3.

Sockalingam, N., Rotgans, J. \& Schmidt, H. (2012). Assessing the Quality of Problems in Problem-Based Learning. International Journal of Teaching and Learning in Higher Education, 24(1), 43-51.

Tsai, C.-W., \& Chiang, Y.-C. (2013). Research trends in problem-based lear ning (PBL) research in e-learning and online education environments: A review of publications in SSCI-indexed journals from 2004 to 2012. British Journal of Education Technology, 44(6), 185-190

Zakaria, M. I., Maat, S. M., \& Khalid, F. (2019). A Systematic Review of Problem Based Learning in Education. Creative Education, 10, 2671-2688.

Zetriuslita, Z., Wahyudin, W., \& Jarnawi, J. (2017). Mathematical Critical Thinking and Curiosity Attitude in Problem Based Learning and Cognitive Conflict Strategy: A Study in Number Theory Course. International Education Studies, 10, 65-78. https://doi.org/10.5539/ies.v10n7p65

Zulkifli, Z. (2016). Keberkesanan Kaedah Pembelajaran Berasaskan Masalah Dalam Meningkatkan Kemahiran Berfikir Aras Tinggi Dan Menyelesaikan Masalah Dalam Kalangan Pelajar. Disertasi Sarjana, Fakulti Pendidikan Teknikal dan Vokasional, Johor, Malaysia: Universiti Tun Hussein Onn.

Zwaal, W., \& Otting, H. (2015). Aligning Principles and Practice in Problem-Based Hospitality Management Education. Journal of Hospitality, Leisure, Sport and Tourism Education, 16, 22-29. https://doi.org/10.1016/j.jhlste.2015.01.001 